\section{Electronic publishing}

SIR - Your editorial comment (Nature 365, 689; 1993) on electronic journals at the Frankfurt Book Fair is timely. As it happens, the general assembly of the International Council of Scientific Unions (ICSU) was taking place at the same time in Santiago de Chile. Progress was reported there on a preliminary study of electronic publishing by members of the ICSU Press (of whom I am one) during 1993.

The ICSU initiative on electronic publishing is particularly concerned with the intellectual property rights in digitally stored scientific texts. A meeting of experts held under the joint auspices of ICSU and UNESCO in Paris last June agreed that there are two major needs: (1) a universally recognized system of bibliographic control of digitally stored scientific texts and (2) a simple method to protect these texts from unauthorized copying or amendment. It was concluded that the time was ripe for scientists and publishers acting together to seek solutions to these.

ICSU Press, at the request of ICSU, has accepted responsibility for monitoring developments in electronic publishing and will endeavour to identify solutions to these problems. The task requires the collaboration of authors, readers and publishers. Although each group has different needs, these are not distinct; indeed, in electronic publishing, the author is often also the publisher as well as the user. However, our meeting of experts, including scientists, lawyers and publishers, as well as executives from WIPO, ICSU and UNESCO, agreed that a common solution must be found if the system of quality control of primary scientific publication is to be protected as electronic journals grow in importance.

We realize that our study is by no means unique, but we may be the first to recognize - and to say publicly - that the matters of concern are common to all interested parties. For this reason, if no other, scientists and publishers should be talking together.

For the present, anybody with a contribution towards solving either of these problems should write to me.

\section{Dennis F. Shaw}

Keble College,

Oxford OX1 3PG, UK

\section{Military students}

SIR - Until last year, unmarried Spanish males under the age of 30 working overseas were exempted from their nine months' military service if they were working abroad for at least three years, but this exemption no longer applies.

As a result, a 25-year-old Spanish graduate student who has been working with me for the past two years and who still has two years' employment ahead of him has been recalled to do his military service immediately. His work for a doctorate will be in jeopardy and my small group working on anoxia in heart cells will be seriously disrupted. I know among my immediate contacts of two other Spanish biologists, in the United States and in Scotland, who have likewise been summarily recalled by the army.

The change in policy probably results from Spain becoming a full member of the European Communities (EC) and the consequent waiving of work permits for Spaniards by other EC countries.

The international scientific community should be aware that employing single, Spanish males under the age of 30 who do not yet know how to fire a rifle or salute a flag is likely to disrupt their research.

\section{Peter Cobboid}

Department of Human Anatomy

and Cell Biology,

University of Liverpool,

POBox 147,

Liverpool L693BX, UK

\section{Mathematics yes, physics no}

SIR - The exciting diversity of life, together with the conflicting requirements for both precision and generality, give biologists especial difficulties with scientific terms. Biology, mathematics and physics all have the need for terminology to be both general and precise. Some recent correspondents ${ }^{1}$ have advocated a physics-like model for biology. Physics deals with a few concepts of wide applicability, so it can afford the luxury of a limited number of terms, each with restricted meaning - the 'one word, one meaning' convention.

Mathematicians have the same need for both precision and generality but they provide a better model for biologists. A general term can be made more precise in a number of ways for a specific action. A general statement may be about all entries in a vector or matrix; a specific statement may use subscripts to refer to either a specific or a general entry. A proof may relate to, say, any monotonic function and a specific function can be substituted for a particular application. A complex equation with many variables can be differentiated 'with respect to' a specific variable. Each of these three ways allows strong general statements to be given a specific meaning at their time of use.

The desire for a very detailed terminology that covers every eventuality has long been a problem in biology. For example ${ }^{2,3}$, any respectable botanical text of the nineteenth century will describe the ten forms of vernation that date back at least to Linnaeus. The texts would include obvolute, equitant, circinal, imbricate, and so on. Most plant scientists would now have to ask what vernation was, let alone know all the modifiers. The terminology is now mercifully forgotten for everyday use.

The philosopher of science, Karl Popper, in his essay 'Against big words ${ }^{4}$ says: "Every intellectual has a very special responsibility . . . he owes it to his fellow men (or to 'society') to represent the results of his study as simply, clearly, and modestly as he can. The worst thing he can do - the cardinal sin - is to try to set themselves up as great prophets vis-a-vis their fellow men and to impress them with puzzling philosophies. Anyone who cannot speak clearly should say nothing and continue to work until he can do so".

When it comes to terminology, biology does not need physics envy. DNA preserve us from potonuons, naptonuons, xaptonuons, exaptations, and halfequitant induplicate vernation.

\section{David Penny}

School of Biological Sciences,

Massey University,

Palmerston North,

New Zealand

1. Brosius, J. \& Gould. S. J. Nature 365, 102 (1993).

2. Clerk, P. K. A Botanical Lexicon (Orr, London, 1837).

3. Henfrey, A. An Elementary Course of Botany: Structural, Physiological and Systematic. (2nd edn by M. T. Masters) (van Vorst, London, 1870)

4. Popper, K. R. In Search of a Better World: Lectures and Essays from Thirty Years (Routledge, London, 1992).

\section{Negative impact}

SIR - The News story about a survey of 250 Indian companies by the Centre for Technology Studies (CTS) to assess the impact of economic liberalization on industrial research and development and innovation ${ }^{1}$ merely reiterates an acknowledged fact documented in the eighth Five-Year Plan².

Moreover, CTS's support for liberalization is negated by its own findings of a fall in research and development expenditure (from 1.1 per cent to 0.8 per cent), and the number of patents (from 22 to 13 ) following liberalization. Thus, calling for more governmental support is not only devoid of scientific legitimacy but also at variance with a policy intended to attract such support from outside.

\section{R. Murmu}

Department of Surgery,

All India Institute of Medical Sciences,

New Delhi-110029,

India

1. Jayaraman K. S. Nature 365, 288, (1993)

2. Research and Development in industry. Eighth Five Year Plan (1992 - 1997); Vol. II (Planning Commission, Plan (1992 - 1997); Vol. Il (Planning Commission. 